\title{
НАВЧАЛЬНО-МЕТОДИЧНЕ ЗАБЕЗПЕЧЕННЯ ПІДГОТОВКИ СТУДЕНТІВ У ВИЩИХ НАВЧАЛЬНИХ ЗАКЛАДАХ МОЗ УКРАЇНИ: СТАН ТА ПЕРШОЧЕРГОВІ ЗАВДАННЯ
}

\author{
I. V. Melnyk, M. O. Polishchuk \\ PI “The Central Higher Medical Education Curriculum Office of Ministry of Helthcare of \\ Ukraine”

\section{EDUCATIONAL AND METHODICAL SUPPLY OF STUDENTS' TRAINING IN HIGHER EDUCATION INSTITUTIONS OF MINISTRY OF HEALTHCARE OF UKRAINE: STATE AND PRIMARY TASKS}

\begin{abstract}
У статті детально висвітлюється стан навчально-методичного забезпечення підготовки студентів у вищих навчальних закладах МОЗ України, дається комплексна оцінка його відповідності вимогам щодо провадження освітньої діяльності у сфері вищої освіти та, згідно з даним аналізом, формуються першочергові завдання щодо удосконалення навчально-методичного забезпечення студентів у ВНЗ МОЗ України.
\end{abstract}

Ключові слова: навчально-методичне забезпечення; вища медична освіта; стандарти вищої освіти; навчальне середовище.

The status of educational and methodological support of students' training in higher education institutions of the Ministry of Healthcare of Ukraine is covered in details in the article, a comprehensive assessment of its compliance with the requirements for carrying out educational activities in higher education is made and, according to this analysis, the emerging priorities for improving educational and methodological support of students' training in higher education institutions of the Ministry of Healthcare of Ukraine are forming.

Key words: educational and methodological support; higher medical education; standards of higher education; learning environment.

Вступ. Підготовка фахівця, який вміє адекватно оцінювати свій професійний рівень і здатний регулярно його підвищувати, може швидко адаптуватися до постійної трансформації у суспільному та професійному середовищі, є одним із основних завдань, поставлених перед сучасною освітою. Результатами сучасної освіти є знання, вміння, навички та особисті якості, втілені у компетенціях, які демонструє студент після закінчення навчання (курсу, модуля, навчальної дисципліни тощо).

Професійна компетентність майбутніх фахівців - це здатність ефективно використовувати набуті знання, вміння і навички; здійснювати активний пошук нового досвіду і визначати його цінність; креативність, здатність до саморозвитку, самоаналізу; вміння вирішувати ту чи іншу проблему тощо [6].

Результат навчання $є$ одним із ключових у сучасній парадигмі вищої освіти - компетентнісному підході до розроблення та реалізації освітніх програм [7].
Як зазначено у Стандартах і рекомендаціях щодо забезпечення якості в Європейському просторі вищої освіти (ESG), ухвалених Міністерською конференцією в Єревані 14-15 травня 2015 року, вища освіта спрямована на досягнення багатьох цілей, включаючи підготовку студентів до активної громадської позиції, до їхньої майбутньої кар’єри (наприклад, сприяючи розвитку їх здатності до працевлаштування), підтримку їхнього особистого розвитку, створення широкої бази передових знань і стимулювання досліджень та інновацій. Забезпечення якості повинно гарантувати навчальне середовище, в якому зміст програм, навчальні можливості та ресурсне забезпечення відповідають цій меті [3].

Мета роботи - проаналізувати стан навчальнометодичного забезпечення підготовки студентів у вищих навчальних закладах МОЗ України, оцінити його відповідність вимогам щодо провадження освітньої діяльності у сфері вищої освіти та окрес-

(C) І. В. Мельник, М. О. Поліщук 
лити першочергові завдання щодо удосконалення навчально-методичного забезпечення студентів у ВНЗ МОЗ України.

Основна частина. Міністерство охорони здоров’ я України та медична освітня спільнота очікували у 2016/2017 навчальному році затвердження в установленому порядку нових стандартів вищої освіти за спеціальностями, визначеними у Постанові Кабінету Міністрів України від 29.04.2015 року № 266 “Про затвердження переліку галузей знань і спеціальностей, за якими здійснюється підготовка здобувачів вищої освіти”.

За підсумками обговорення на XIII Всеукраїнській науково-практичній конференції з міжнародною участю “Актуальні питання якості медичної освіти” (м. Тернопіль, 12-13 травня 2016 року), розроблені робочими групами МОЗ України (наказ МОЗ України від 09.11.2015 року № 733 “Про утворення координаційної та робочих груп для формування переліку спеціалізацій та пропозицій до стандартів вищої освіти за спеціальностями галузі знань “Охорона здоров’я”) проекти стандартів вищої освіти за спеціальностями галузі знань 22 “Охорона здоров’я”: 222 “Медицина”, 221 “Стоматологія”, 226 “Фармація”, 224 “Технології медичної діагностики та лікування”, 225 “Медична та психологічна реабілітація”, 227 “Фізична реабілітація”, 223 “Медсестринство”, представлені до Науково-методичної комісії з охорони здоров’ та соціального забезпечення Міністерства освіти та науки України для подальшого затвердження в установленому порядку.
Проекти стандартів базуються на компетентнісному підході і поділяють філософію визначення вимог до фахівця, закладену в основу Болонського процесу та в міжнародному Проекті Європейської комісії “Гармонізація освітніх структур в Європі” (Tuning Educational Structures in Europe, TUNING), ураховують вимоги Директиви Європейського Союзу щодо визнання професійних кваліфікацій від 2005 року (№ 2005/36/ЄС, з поправками Директиви Європейського Союзу № 2013/55/ЄС).

На підставі зазначених проектів стандартів було розроблено примірні навчальні плани підготовки фахівців другого (магістерського) рівня вищої освіти галузі знань 22 “Охорона здоров’ я” за спеціальностями: 222 “Медицина”, 221 “Стоматологія”, 226 “Фармація”, 225 “Медична та психологічна реабілітація”, які затверджені МОЗ України 26.07.2016 року та запроваджені у навчальний процес з 2016/2017 навчального року.

Започатковано підготовку нового покоління програм з усіх дисциплін вказаних навчальних планів, починаючи 3 тих, які вивчаються на 1 курсі. При цьому MO3 України запровадило (лист від 28.07.2016 року № 23-01-9/268) нову форму підготовки примірних програм другого (магістерського) рівня вищої освіти, яка містить розділ щодо компетентностей та результатів навчання, формуванню яких сприяє дисципліна (інтегральна, загальні та спеціальні (фахові, предметні). Рекомендовано компетентності деталізувати відповідно до дескрипторів НРК у формі матриці компетентностей.

\section{Матриця компетентностей}

\begin{tabular}{|l|c|c|c|c|c|}
\hline № & Компетентність & Знання & Уміння & Комунікація & Автономія та відповідальність \\
\hline
\end{tabular}

Результати навчання на компетентнісних засадах формулюються як: “здатність застосовувати”, “здатність аналізувати”, “здатність оцінювати”, “здатність відтворити практичну навичку”, “здатність провести клінічне обстеження”, “здатність надати невідкладну допомогу” тощо.

Програма має містити оновлену основну (базову) літературу та посилання на інформаційні ресурси.

У 2016 році розроблено та затверджено МO3 України в установленому порядку 94 примірні програми з дисциплін та курсів за вибором 1-го року навчання підготовки фахівців другого (магістерського) рівня вищої освіти, галузі знань 22 “Охорона здоров'я”, а саме:
- 29 - кваліфікації освітньої “Магістр медицини”, кваліфікації професійної “Лікар”;

- 25 - кваліфікації освітньої “Магістр стоматології”, кваліфікації професійної “Лікар-стоматолог”;

- 25 - кваліфікації освітньої “Магістр медичної та психологічної реабілітації”, кваліфікації професійної “Лікар-реабілітолог”, “Лікар-психолог”; - 15 - кваліфікації освітньої “Магістр фармації”. Розробка програм була доручена фахівцям опорних кафедр, визначених у наказі МОЗ України від 23.08.2011 року № 532 “Про внесення змін до наказу МОЗ України від 26.02.2003 року № 86”. Доцільно нагадати про те, що згідно з розділом 2 Примірного положення про опорну кафедру ви- 
щих медичних (фармацевтичного) навчальних закладів III-IV рівнів акредитації та закладів післядипломної освіти МОЗ України, затвердженого зазначеним наказом, завданнями опорних кафедр $\epsilon$, зокрема:

- узагальнення та впровадження передового досвіду викладання однопрофільних дисциплін у вищих навчальних закладах МОЗ України (далі - ВНЗ МОЗ України);

- розробка пропозицій і рекомендацій щодо удосконалення організації та методики підвищення якості підготовки студентів, інтернів, робота над створенням нормативних документів з вищої медичної та фармацевтичної освіти;

- створення та введення у навчальний процес ВН3 МОЗ України удосконалених навчальних планів і програм, міжкафедральних підручників, посібників, навчальних відеофільмів тощо;

- участь у розробці новітніх технологій навчання та державних стандартів освіти [6].

У квітні 2017 року у відповідних листах Державна установа “Центральний методичний кабінет 3 вищої медичної освіти МОЗ України” (далі-ЦМК, Кабінет) доручила фахівцям опорних кафедр розробку програм 2 року навчання підготовки фахівців другого (магістерського) рівня вищої освіти галузі знань 22 “Охорона здоров’я” (34 дисципліни, 33 курси за вибором). Затверджено МОЗ України 18 програм з нормативних дисциплін та 14 курсів за вибором, завершується підготовка решти програм.

Таким чином, одним із першочергових завдань $є$ підготовка програм нового покоління з дисциплін усіх навчальних планів, за якими здійснюється додипломна підготовка фахівців другого (магістерського) рівня вищої освіти галузі знань 22 “Охорона здоров’я”, з урахуванням як сучасних досягнень 3 відповідної галузі вітчизняної і світової медичної та фармацевтичної науки, так і досвіду викладання дисципліни у ВНЗ. Відповідно до примірних програм, затверджених МОЗ України, вищі навчальні заклади мають розробити робочі програми з кожної навчальної дисципліни.

Слід наголосити на тому, що відповідно до вимог з провадження освітньої діяльності у сфері вищої освіти, зазначених у Ліцензійних умовах провадження освітньої діяльності закладів освіти (постанова Кабінету Міністрів України від 30.12.2015 року № 1187, далі - Ліцензійні умови), зокрема у розділі “Технологічні вимоги щодо забезпечення провадження освітньої діяльності у сфері вищої освіти” (далі - Технологічні вимоги) зазначено, що обов'язковими складовими здійснення навчального процесу, окрім наявності робочої програми з кожної дисципліни навчального плану, є: комплекс навчально-методичного забезпечення; робочі програми практик; забезпеченість студентів навчальними матеріалами; методичні матеріали для проведення атестації здобувачів [1]. При цьому згідно із статтею 47 розділу IX “Організація освітнього процесу” Закону України “Про вищу освіту” та відповідними дорученнями МОН України вищі навчальні заклади самостійно розробили і затвердили рішенням вченої ради положення про організацію навчального процесу, в яких і мають бути детально прописані вимоги до підготовки та ведення навчально-методичної документації, контролю з боку завідувачів кафедр за веденням кафедральної документації, зокрема оновленням методичних рекомендацій для студентів, особливо для організації самостійної роботи.

Необхідною умовою належного викладання дисциплін, особливо професійно-орієнтованих, є щорічне оновлення методичних розробок для студентів. На цьому був зроблений наголос під час моніторингу стану організації навчального процесу у вищих медичних та фармацевтичних навчальних закладах і закладах післядипломної освіти, підпорядкованих МОЗ України, який проводився у першому півріччі 2016 року на виконання наказу MO3 України від 24.10.2012 року № 834 “Про навчально-методичну діяльність вищих медичних та фармацевтичних навчальних закладів I-IV рівнів акредитації”. Моніторинг, проведення якого було заплановане у другому півріччі 2016 року, з організаційно-виробничих причин був перенесений МО3 України на 2017 рік (лист за підписом заступника міністра охорони здоров’я О. Лінчевського від 02.12.2016 року № 08.1-30/31522).

Таким чином, наступним з нагальних завдань 3 удосконалення навчально-методичного забезпечення навчального процесу є організація належної підготовки на кафедрах професорсько-викладацьким складом та контроль з боку адміністрації навчальних закладів за постійним оновленням методичних розробок до практичних (семінарських/лабораторних) занять, особливо для організації самостійної роботи студентів.

Слід також зробити наголос на тому, що у зазначених Технологічних вимогах (додаток 14 до Ліцензійних умов) є роз'яснення того, що забезпеченістю 
навчальними матеріалами вважається наявність підручників, навчальних посібників, конспектів лекцій, хрестоматій згідно з переліком рекомендованої літератури з розрахунку: один примірник на п’ять осіб фактичного контингенту студентів, їх наявність в електронній формі для необмеженої кількості користувачів, з дотриманням вимог законодавства про інтелектуальну власність. Для вибіркових навчальних дисциплін дозволяється використання навчальних матеріалів лише в електронній формі [1].

Як свідчать підсумки щорічного аналізу стану забезпеченості підручниками і посібниками студентів ВНЗ МОЗ України (на 01.09.2016 року), загальний середній показник забезпеченості ВНЗ МО3 України оновленими підручниками у 2016/2017 навчальному році складає 31 \%, посібниками 19 \% (у порівнянні з 2015/2016 навчальним роком: підручниками - 25 \%, посібниками - 17 \%). При цьому, ураховуючи те, що у 2016/2017 навчальному році згідно з новими Ліцензійними умовами обрахунки здійснювались 3 розрахунку: 1 книга на 5-х студентів, тоді як у 2015/2016 навчальному році - 3 розрахунку: 1 книга на 3-х студентів, можна зробити висновок, що навіть “формального” суттєвого покращення забезпеченості студентів ВН3 МO3 України підручниками і посібниками не спостерігається (табл. 1).

Зокрема, середні показники забезпеченості у 2016/2017 навчальному році книгами студентів спеціальностей “Лікувальна справа”, “Педіатрія” та “Медико-профілактична справа” становлять: підручниками - 42 \%, посібниками - 21 \% (у 2015/2016 навчальному році: підручниками - 35 \%, посібниками - 17 \%). Найбільш суттєво зросли показники забезпечення підручниками і посібниками

Таблиця 1. Стан забезпеченості підручниками і посібниками студентів ВНЗ МОЗ України у 2015/2016 та 2016/2017 навчальних роках

\begin{tabular}{|c|c|c|c|c|}
\hline \multirow{2}{*}{ Спеціальність } & \multicolumn{2}{|c|}{$\begin{array}{c}\text { Середній показник за 2015/2016 навч. } \\
\text { рік (\%)* }\end{array}$} & $\begin{array}{c}\text { Середній показник за 2016/2017 навч. } \\
\text { рік (\%)** }\end{array}$ \\
\cline { 2 - 5 } & підручники & посібники & підручники & посібники \\
\hline $\begin{array}{c}\text { “Лікувальна справа”, } \\
\text { “Педіатрія”, “Медико- } \\
\text { профілактична справа” }\end{array}$ & 35 & 17 & 42 & 21 \\
\hline “Стоматологія” & 33 & 13 & 56 & 24 \\
\hline “Фармація” & 21 & 15 & 24 & 17 \\
\hline $\begin{array}{c}\text { “Клінічна фармація” } \\
\text { косметичних засобів” }\end{array}$ & 20 & 13 & 25 & 20 \\
\hline $\begin{array}{c}\text { “Технологія фармацевтичних } \\
\text { препаратів” }\end{array}$ & 9 & 22 & 16 & 22 \\
\hline “Медична психологія” & 37 & 22 & 29 & 15 \\
\hline
\end{tabular}

Примітки:

1. * - з розрахунку: 1 книга на 3-х студентів.

2. ** - 3 розрахунку: 1 книга на 5-х студентів.

студентів стоматологічних факультетів. Найгірші показники забезпеченості у 2016/2017 навчальному році навчальними книгами студентів спеціальності “Технологія фармацевтичних препаратів”: підручниками - 16 \%, посібниками - 22 \% (у 2015/2016 навчальному році: підручниками - $9 \%$, посібниками - 14 \%) та спеціальності “Клінічна фармація”: підручниками - 24 \%, посібниками - 11 \% (у 2015/2016 навчальному році: підручниками - 20 \%, посібниками - $13 \%$ ).

Ураховуючи зазначене, актуальним завданням щодо належної організації навчального процесу $\epsilon$ вжиття заходів щодо покращення забезпечення здобувачів вищої освіти у ВНЗ МОЗ України сучасною навчально-методичною літературою (3 урахуванням Ліцензійних умов).

Найбільша кількість електронних видань, які надійшли до фондів бібліотек ВНЗ МОЗ України протягом 2012-2016 років (табл. 2), у: Запорізькому державному медичному університеті (2100); Одеському національному медичному університеті (1005) та Харківському національному медичному університеті (724). При цьому найбільша кількість електронних видань, авторами яких $€$ фахівці навчального закладу, у: Запорізькому державному медичному університеті (2030); Харківському національному медичному університеті (700) та ДВНЗ “Тернопільський державний 
Таблиця 2. Кількість електронних видань, які надійшли до фондів бібліотек ВНЗ МОЗ України протягом 2012-2016 років (станом на 01.09.2016 року)

\begin{tabular}{|c|c|c|c|c|c|c|c|c|c|}
\hline \multirow{3}{*}{$\begin{array}{c}\text { ВН3 } \\
\text { МО3 } \\
\text { України }\end{array}$} & \multirow{3}{*}{$\begin{array}{c}\text { Кількість } \\
\text { електронних } \\
\text { видань }\end{array}$} & \multicolumn{8}{|c|}{3 них: } \\
\hline & & \multicolumn{2}{|c|}{$\begin{array}{c}\text { з дозволами МОН, МОЗ } \\
\text { України, ЦМК, вчених } \\
\text { рад ВНЗ }\end{array}$} & \multirow{2}{*}{$\begin{array}{c}\text { кількість } \\
\text { видань, } \\
\text { авторами } \\
\text { яких є } \\
\text { фахівці } \\
\text { навч. } \\
\text { закладу }\end{array}$} & \multirow{2}{*}{$\begin{array}{c}\text { кількість } \\
\text { видань, } \\
\text { які } \\
\text { надійшли } \\
\text { з дозволу } \\
\text { авторів }\end{array}$} & \multirow{2}{*}{$\begin{array}{c}\text { кількість } \\
\text { видань, } \\
\text { які } \\
\text { отримано } \\
\text { з вільних } \\
\text { джерел }\end{array}$} & \multirow[t]{2}{*}{ укр. } & \multirow[t]{2}{*}{ poc. } & \multirow{2}{*}{$\begin{array}{l}\text { іншими } \\
\text { мовами }\end{array}$} \\
\hline & & підручники & посібники & & & & & & \\
\hline БДМУ & 15 & 2 & 3 & 12 & 12 & 3 & 14 & & 1 \\
\hline ВНМУ & 86 & & & & 6 & 80 & 62 & 12 & 12 \\
\hline ДМА & 43 & 5 & 38 & 42 & 1 & & 32 & 7 & 4 \\
\hline ЗДМУ & 2100 & 18 & 350 & 2030 & 2100 & & 1585 & 157 & 358 \\
\hline ІФНМУ & 131 & 31 & 100 & 94 & 12 & 25 & 107 & 14 & 10 \\
\hline ЛНМУ & 5 & 1 & 4 & 4 & 3 & 2 & 4 & & 1 \\
\hline HМУ & 79 & 39 & 23 & 1 & 78 & 1 & 21 & 47 & 11 \\
\hline НФУ & 386 & 31 & 123 & 386 & 386 & & 224 & 89 & 73 \\
\hline OHМУ & 1005 & 101 & 148 & 44 & 9 & 952 & 239 & 443 & 323 \\
\hline ТДМУ & 564 & & 564 & 564 & 564 & & 344 & 111 & 109 \\
\hline УМСA & 667 & 6 & 53 & 560 & 604 & 63 & 256 & 231 & 180 \\
\hline ХНМУ & 724 & 10 & 57 & 700 & 724 & & 319 & 240 & 165 \\
\hline ЛДМУ & 194 & 10 & 57 & 3 & 3 & 191 & 63 & 124 & 7 \\
\hline Всього: & 5999 & 254 & 1520 & 4440 & 4502 & 1317 & 3270 & 1475 & 1254 \\
\hline $\begin{array}{l}\text { Всього } \\
\text { у 2011- } \\
\text { 2015: }\end{array}$ & 6143 & 407 & 1330 & 3969 & 2992 & 1922 & 2986 & 1780 & 1372 \\
\hline
\end{tabular}

медичний університет імені I. Я. Горбачевського МО3 України” (564).

Необхідно нагадати, що у примітці додатка 12 “Кадрові вимоги щодо забезпечення провадження освітньої діяльності у сфері вищої освіти” до Ліцензійних умов зазначено: “Відповідність спеціальності викладача навчальній дисципліні визначається відповідністю його спеціальності згідно з документами про вищу освіту або про науковий ступінь, або про вчене звання або науковою спеціальністю, або досвідом практичної роботи за відповідним фахом не менше п'яти років, або проходженням відповідного науково-педагогічного стажування тривалістю не менше шести місяців та наявністю трьох одноосібних публікацій з цієї навчальної дисципліни у рецензованих закордонних або фахових наукових виданнях України, або виданого підручника чи навчального посібника з цієї навчальної дисципліни згідно з вимогами МОН”. Для визначення рівня наукової та професійної активності науково-педагогічного (наукового) працівника використовуються, зокрема, такі показники: наявність наукової публікації у періодичному виданні, яке включено до наукометричних баз, зо- крема Scopus або Web of Science Core Collection, рекомендованих МОН (п. 1); наявність наукових публікацій у наукових виданнях, включених до переліку наукових фахових видань України, та/або авторських свідоцтв, та/або патентів загальною кількістю п'ять досягнень (п. 2); наявність виданого підручника чи навчального посібника, що рекомендований МОН, іншим центральним органом виконавчої влади або вченою радою закладу освіти, або монографії (у разі співавторства - 3 фіксованим власним внеском) (п. 3); наявність виданих навчально-методичних посібників/посібників для самостійної роботи студентів та дистанційного навчання/конспектів лекцій/практикумів/методичних вказівок/рекомендацій загальною кількістю три найменування (п. 14) [1].

Зважаючи на роль забезпечення здобувачів вищої освіти сучасною навчальною книгою в організації освітнього процесу, питання забезпечення якісної підготовки рукописів, у тому числі електронних підручників і посібників, та їх належної експертизи з урахування вимог наказу МОЗ України від 19.01.2015 року № 20 “Про організацію підготовки навчальної та навчально-методичної літератури” 
із змінами, внесеними наказом МОЗ України від 04.05.2016 року № 407, включено до Плану пріоритетних заходів вищих навчальних закладів та закладів післядипломної освіти МОЗ України у 2016/2017 навчальному році, затвердженого наказом МОЗ України від 05.10.2016 року № 1043.

Ураховуючи те, що у 2017/2018 навчальному році підготовка фахівців другого (магістерського) рівня вищої освіти галузі знань 22 “Охорона здоров’я” буде здійснюватись на 1 та 2 курсах, а студенти 3-6 курсів спеціальностей “Лікувальна справа”, “Педіатрія”, “Медико-профілактична справа” і “Медична психологія” і 3-5 курсів спеціальностей “Стоматологія”, “Фармація”, “Клінічна фармація”, “Технологія фармацевтичних препаратів” та “Технологія парфумерно-косметичних засобів” будуть навчатись за навчальними планами підготовки фахівців освітньо-кваліфікаційного рівня “Спеціаліст”, ЦМК у відповідних листах звернулась до ректорів ВН3 MO3 України з проханням доручити фахівцям профільних опорних кафедр вивчити питання щодо доцільності оновлення (внесення змін) програм, які були затверджені МОЗ України до 2014 року, з урахуванням досвіду викладання та сучасних досягнень відповідних галузей медицини та фармації.

Зокрема оновлено програму з дисципліни “Загальна практика - сімейна медицина” для вищих навчальних закладів МОЗ України для спеціальностей “Лікувальна справа”, “Педіатрія”, “Медикопрофілактична справа” (обсяг 3 кредити, 40 годин аудиторних, 6 рік начання, затверджена МОЗ України 20 грудня 2016 року) на виконання доручення Кабінету Міністрів України від 11 липня 2016 року № 24896/1/1-16 про розгляд Рекомендацій у Комітеті Верховної Ради щодо питань охорони здоров’ я на тему “Сімейна медицина - шанс на здоров’ я та значне зменшення особистих витрат на лікування”, з урахуванням компетенцій, визначених Європейськими стандартами підготовки сімейних лікарів (WONCA 2013), Європейської академії викладачів сімейної медицини (EURACT), глобальних стандартів підвищення якості медичної освіти (WFME, 2009), рекомендацій ВООЗ “Оцінювання системи реабілітації в Україні”. Отже, актуальним є завдання оновлення і типових програм навчальних планів 3-6 (5) курсів додипломної підготовки фахівців освітньо-кваліфікаційного рівня “Спеціаліст” у ВМ(Ф)НЗ МОЗ України.

Відповідно до постанови Кабінету Міністрів України від 1 лютого 2017 року № 53 внесені зміни до переліку спеціальностей галузі знань 22 “Охорона здоров’я”, за якими здійснюється підготовка здобувачів вищої освіти у вищих медичних (фармацевтичних) закладах, зокрема включені спеціальності: 225 “Медична психологія” (замість 225 “Медична та психологічна реабілітація” згідно з постановою Кабінету Міністрів України від 29 квітня 2015 року № 266, далі - постанова № 266), 226 “Фармація, промислова фармація” (замість 226 “Фармація” згідно з постановою № 266), 227 “Фізична терапія, ерготерапія” (замість 227 “Фізична реабілітація” згідно з постановою № 266), а також додатково введено спеціальності 228 “Педіатрія” та 229 “Громадське здоров’я”. МОН України повідомило вищі навчальні заклади (лист за підписом першого заступника міністра охорони здоров'я В. В. Ковтунця від 24.02.2017 року № 1/9-106) про необхідність ліцензування в установленому законодавством порядку спеціальностей 225 “Медична психологія”, 228 “Педіатрія” та 229 “Громадське здоров'я”.

Ураховуючи зміни, внесені до переліку спеціальностей галузі знань 22 “Охорона здоров’я” відповідно до постанови Кабінету Міністрів України від 01.02.2017 року № 53, на доручення ЦМК (лист від 29.03.2017 року № 23-01-9/118) фахівцями робочої групи для формування пропозицій до стандартів вищої освіти за спеціальністю 225 “Медична та психологічна реабілітація” (визначена наказом МО3 України від 09.11.2015 року № 733) підготовлено проект плану підготовки фахівців другого (магістерського) рівня вищої освіти галузі знань 22 “Охорона здоров’я” за спеціальністю 225 “Медична психологія”, який надісланий для опрацювання у ВНЗ МОЗ України та після обговорення пропозицій буде запропонований на затвердження в установленому порядку. Затвердження в установленому порядку Примірного плану підготовки магістрів зазначеної спеціальності до початку 2017/2018 навчального року є дуже нагальним для тих ВН3 МО3 України, які отримають ліцензію на провадження освітньої діяльності за спеціальністю 225 “Медична психологія”.

Відповідно до Умов прийому на навчання до вищих навчальних закладів України в 2017 році, затверджених наказом Міністерства освіти і науки України від 13.10.2016 року № 1236, ЦМК було доручено фахівцям науково-методичної лабораторії 3 питань підготовки стоматологів ВДНЗ “Українська медична стоматологічна академія” опрацювати про- 
ект навчального плану додипломної підготовки фахівців другого (магістерського) рівня вищої освіти галузі знань 22 “Охорона здоров’я”, спеціальності 221 “Стоматологія”, які попередньо здобули освітньо-кваліфікаційний рівень молодшого спеціаліста 5.12010104 “Стоматологія” та 12010106 “Стоматологія ортопедична” для подальшого навчання у вищих навчальних закладах МОЗ України. Також Кабінет доручив фахівцям ДВНЗ “Івано-Франківський національний медичний університет” та Національного медичного університету імені О. О. Богомольця опрацювати проект навчального плану додипломної підготовки фахівців другого (магістерського) рівня вищої освіти галузі знань 22 “Охорона здоров’я”, спеціальності 222 “Медицина”, які попередньо здобули освітньо-кваліфікаційний рівень молодшого спеціаліста 5.12010101 “Лікувальна справа” та 5.12010102 “Сестринська справа”. Зазначені проекти навчальних планів надіслані для опрацювання у ВНЗ МОЗ України та після обговорення пропозицій будуть запропоновані на затвердження в установленому порядку.

Залишається дуже актуальним питання формування уніфікованих підходів до розуміння окремих норм Закону України “Про вищу освіту” в умовах відсутності підзаконних актів чи роз'яснень з боку МОН України. Наприклад, у пункті першому частини першої статті 1 “Основні терміни та їх визначення” Закону України “Про вищу освіту” наведено визначення автономії вищого навчального закладу, що передбачає самостійність, незалежність і відповідальність вищого навчального закладу у прийнятті рішень стосовно розвитку академічних свобод, організації освітнього процесу, наукових досліджень, внутрішнього управління, економічної та іншої діяльності, самостійного добору і розстановки кадрів у межах, встановлених цим законом.

Навчальний заклад сам вирішує, як запроваджувати, контролювати та переглядати політику забезпечення якості надання освітніх послуг, розробляє програми, положення, включає відповідні позиції до документів різного рівня. Ці документи відрізняються рівнем прийняття (від наказів ректора до рішень вчених рад) і мають різний ступінь “легітимності” з точки зору зовнішніх органів (Рахункова палата Верховної Ради України, Державна фінансова інспекція України, Державна інспекція навчальних закладів тощо), що потенційно може призвести до застосування до ВНЗ тих чи інших санкцій. Саме тому є потреба у запровадженні єди- них (типових) вимог до документів цього спрямування [4].

В абзаці другому частини другої статті 56 Закону України “Про вищу освіту” передбачено, що норми часу навчальної роботи у вищих навчальних закладах державної та комунальної форм власності (крім вищих навчальних закладів, що мають статус національного або дослідницького) визначаються центральним органом виконавчої влади у сфері освіти і науки за погодженням із заінтересованими державними органами. Підзаконні акти на виконання цієї норми Закону України “Про вищу освіту” на сьогодні відсутні.

Є дуже очікуваною розробка зазначених у наказі МОН України від 27.10.2016 року № 1288 “Про затвердження Плану заходів із вдосконалення нормативно-правової бази вищої освіти на 2016/2017 навчальний рік” нової редакції Положення про поновлення, переведення, надання академічних відпусток та відрахування здобувачів вищої освіти на виконання статті 46 Закону України “Про вищу освіту” (термін: грудень 2016 року - січень 2017 року), а також проекту постанови Кабінету Міністрів України про затвердження нормативів чисельності здобувачів вищої освіти на одну штатну посаду науково-педагогічного працівника у ВН3 державної форми власності (термін: грудень 2016 року). Проекти зазначених документів на сьогодні не оприлюднені.

Згідно із статтею 6 “Атестація здобувачів вищої освіти” Закону України “Про вищу освіту”, атестація осіб, які здобувають ступінь молодшого бакалавра, бакалавра чи магістра, здійснюється екзаменаційною комісією, до складу якої можуть включатися представники роботодавців та їх об’єднань, відповідно до положення про екзаменаційну комісію, затвердженого вченою радою вищого навчального закладу.

Однак механізми реалізації участі роботодавців у забезпеченні якості вищої освіти нормативно не врегульовані, зокрема і процедура оплати роботи голів (членів) екзаменаційних комісій, якщо вони не $є$ науково-педагогічними працівниками цього закладу.

3 огляду на вищенаведене, мали б бути уніфікованими підходи до розуміння норм Закону України “Про вищу освіту”, які б сприяли визначенню вищими навчальними закладами можливих способів виконання законодавчих положень для забезпечення обрання оптимального внутрішнього правозас- 
тосування. Залишається актуальною доцільність опрацювання спільно з відповідними фахівцями навчальних закладів рекомендацій щодо підготовки положень про організацію освітнього процесу у ВНЗ МОЗ України, про кафедру ВНЗ МОЗ України, нормування часу у ВНЗ МОЗ України та інших [5].

Висновки. Таким чином, першочерговими завданнями щодо удосконалення навчально-методичного забезпечення студентів у ВНЗ МОЗ України є:

1. Затвердження в установленому порядку проектів стандартів вищої освіти за спеціальностями галузі знань 22 “Охорона здоров’я”: 222 “Медицина”, 221 “Стоматологія”, 224 “Технології медичної діагностики та лікування”, 223 “Медсестринство”.

2. Створення проектів стандартів та проектів навчальних планів додипломної підготовки магістрів за спеціальностями галузі знань 22 “Охорона здоров’я” відповідно до змін, визначених у постанові Кабінету Міністрів України від 1 лютого 2017 року № 53.

3. Підготовка програм нового покоління з дисциплін усіх навчальних планів, за якими здійснюється додипломна підготовка фахівців другого (магістерського) рівня вищої освіти галузі знань 22 “Охорона здоров’я”, з урахуванням як сучасних досягнень 3 відповідної галузі вітчизняної і світової медичної та фармацевтичної науки, так і досвіду викладання дисципліни у ВНЗ. Розробка вищими навчальними закладами робочих програм з кожної навчальної дисципліни відповідно до примірних програм, затверджених MO3 України. Оновлення типових програм відповідно до дисциплін навчальних планів 3-6 (5) курсів додипломної підготовки фахівців освітньо-кваліфікаційного рівня "Спеціаліст" у ВМ(Ф)НЗ МОЗ України.

4. Вжиття заходів щодо покращення забезпечення здобувачів вищої освіти у ВНЗ МОЗ України

\section{Список літератури}

1. Ліцензійні умови провадження освітньої діяльності закладів освіти : Постанова Кабінету Міністрів України від 30.12.2015 року № 1187.

2. Про внесення змін до наказу МОЗ України від 26.02.2003 року № 86 : наказ МОЗ України від 23.08.2011 року № 532.

3. Стандарти і рекомендації щодо забезпечення якості в Європейському просторі вищої освіти (ESG): ухвалено Міністерською конференцією в Єревані 14-15 травня 2015 року. - К. : ТОВ “Поліграф плюс”, 2015. - С. 6-7.

4. Оцінка відповідності існуючих в Україні практик забезпечення якості вищої освіти європейським стандар- україномовною сучасною навчально-методичною літературою (з урахуванням Ліцензійних умов). Забезпечення якісної підготовки рукописів, у тому числі електронних підручників і посібників, та їх належної експертизи з урахування вимог наказу МОЗ України від 19.01.2015 року № 20 “Про організацію підготовки навчальної та навчально-методичної літератури” із змінами, внесеними наказом МО3 України від 04.05.2016 року № 407.

5. Організація належної підготовки на кафедрах професорсько-викладацьким складом та контроль з боку адміністрації навчальних закладів за постійним оновленням методичних розробок до практичних (семінарських/лабораторних) занять, особливо для організації самостійної роботи студентів.

6. Завершення опрацювання проектів навчальних планів додипломної підготовки фахівців другого (магістерського) рівня вищої освіти галузі знань 22 “Охорона здоров’я”, спеціальності 221 “Стоматологія”, які попередньо здобули освітньо-кваліфікаційний рівень молодшого спеціаліста 5.12010104 “Стоматологія” та 12010106 “Стоматологія ортопедична” спеціальності 222 “Медицина”, які попередньо здобули освітньо-кваліфікаційний рівень молодшого спеціаліста 5.12010101 “Лікувальна справа” та 5.12010102 “Сестринська справа”, для подальшого навчання у вищих навчальних закладах МОЗ України, відповідно до Умов прийому на навчання до вищих навчальних закладів України в 2017 році, затверджених наказом Міністерства освіти і науки України від 13.10.2016 року № 1236.

7. Опрацювання спільно з відповідними фахівцями навчальних закладів рекомендацій щодо підготовки положень про організацію освітнього процесу у ВН3 МОЗ України, про кафедру ВНЗ МОЗ України, нормування часу у ВНЗ МОЗ України та інших.

там ESG-2015 / В. А. Бугров, А. П. Гожик, А. М. Пижик [та ін.] // Тематичний випуск “Європейська інтеграція вищої освіти України в контексті Болонського процесу”: теоретичний та науково-методичний часопис “Вища освіта України”. - К. : Інститут вищої освіти НАПН України, 2016. - № 4 (дод. 2). - С. 6-12.

5. Організація навчального процесу у вищих навчальних закладах Міністерства охорони здоров’я України в умовах впровадження Закону України “Про вищу освіту” (за підсумками моніторингу в 2016 р.) / Ю. С. П'ятницький, І. В. Мельник, М. О. Поліщук, Ю. І. Фисун // Актуальні питання якості медичної осві- 
ти : матеріали XIII Всеукр. наук.-практ. конф. з міжнар. участю. - Тернопіль : Укрмедкнига, 2016. - С. 22-26.

6. Оцінювання професійної компетентності майбутніх фахівців як цілісна система / Л. М. Дибкова // Тематичний випуск “Європейська інтеграція вищої освіти України в контексті Болонського процесу”: теоретичний та науково-методичний часопис “Вища освіта України”. К. : Інститут вищої освіти НАПН України, 2015. - № 3

\section{References}

1. Litsenziini umovy provadzhennia osvitnoi diialnosti zakladiv osvity: Postanova Kabinetu Ministriv Ukrainy vid 30.12.2015 roku № 1187 [Licence provisions of education activities implementation by educational institutions: Order of the Cabinet of Ministers of Ukraine of December 30, 2015, № 1187] [in Ukrainian].

2. Pro vnesennia zmin do nakazu MOZ Ukrainy vid 26.02.2003 roku № 86 : nakaz MOZ Ukrainy vid 23.08.2011 roku № 532 [On amendgments being made to the Order of Ministry of Healthcare of Ukraine of February 26, 2003 № 86: Order of Ministry of Healthcare of Ukraine of August 23, 2011 № 532] [in Ukrainian].

3. Standarty i rekomendatsii shchodo zabezpechennia yakosti v Yevropeiskomu prostori vyshchoi osvity (ESG): ukhvaleno Ministerskoiu konferentsiieiu v Yerevani 14-15 travnia 2015 roku [Standard and Recommended practices on quality assurance in European higher education environment (ESG): approved at Ministry conference in Yerevan on May 14-15, 2015]. (2015). Kyiv: TOV "Polihraf plius” [in Ukrainian].

4. Bukrov, V.A., Hozhyk, A.P., \& Pyzhyk, A.M. (2016). Otsinka vidpovidnosti isnuiuchykh v Ukraini praktyk zabezpechennia yakosti vyshchoi osvity yevropeiskym standartam ESG-2015 [Ukrainian practice of higher education quality compliance to European standards ESG-2015 assesment]. Tematychnyi vypusk "Yevropeiska intehratsiia vyshchoi osvity Ukrainy v konteksti Bolonskoho protsesu": teoretychnyi ta naukovo-metodychnyi chasopys "Vyshcha osvita Ukrainy" - Special issue "European integration of Higher education of Ukraine in the context of Bologna process": theoretic, academic and research journal "Higher education of Ukraine" (Issue 4), (pp. 6-12). Kyiv: Instytut vyshchoi osvity NAPN Ukrainy [in Ukrainian].

5. Piatnytskyi, Yu.S., Melnyk, I.V., Polishchuk, M.O., \& Fysun, Yu.I. (2016). Orhanizatsiia navchalnoho protsesu (дод. 2). - С. 23-27.

7. Програмні результати навчання: вимоги до формулювання / Ю. М. Рашкевич // Тематичний випуск “Європейська інтеграція вищої освіти України в контексті Болонського процесу”: теоретичний та науково-методичний часопис “Вища освіта України”. - К. : Інститут вищої освіти НАПН України, 2016. - № 4 (дод. 2). - С. 12.

u vyshchykh navchalnykh zakladakh Ministerstva okhorony zdorovia Ukrainy $\mathrm{v}$ umovakh vprovadzhennia Zakonu Ukrainy "Pro vyshchu osvitu” (za pidsumkamy monitorynhu v 2016 r.) [Learning process organization at higher educational institutions of Ministry of Healthcare of Ukraine under the conditions of Higher Education Act of Ukraine introduction]. Aktualni pytannia yakosti medychnoi osvity: materialy XIII Vseukr. nauk.-prakt. konf. z mizhnar. uchastiu - Current issues of medical education quality: proceedings of XIII All-Ukrainian Scientific and Practical Conference with International Participation (pp. 22-26). Ternopil: Ukrmedknyha [in Ukrainian].

6. Dybkova, L.M. (2015). Otsiniuvannia profesiinoi kompetentnosti maibutnikh fakhivtsiv yak tsilisna systema [Professional competency of future professionals evaluation as an integral system]. Tematychnyi vypusk "Yevropeiska intehratsiia vyshchoi osvity Ukrainy v konteksti Bolonskoho protsesu": teoretychnyi ta naukovo-metodychnyi chasopys "Vyshcha osvita Ukrainy" - Special issue "European integration of Higher education of Ukraine in the context of Bologna process": theoretic, academic and research journal "Higher education of Ukraine" (Issue 3), (pp. 23-27). Kyiv: Instytut vyshchoi osvity NAPN Ukrainy [in Ukrainian].

7. Rashkevych, Yu.M. (2016). Prohramni rezultaty navchannia: vymohy do formuliuvannia [Programme results of education: requirements for formulation]. Tematychnyi vypusk "Yevropeiska intehratsiia vyshchoi osvity Ukrainy v konteksti Bolonskoho protsesu”: teoretychnyi ta naukovometodychnyi chasopys "Vyshcha osvita Ukrainy" - Special issue "European integration of Higher education of Ukraine in the context of Bologna process": theoretic, academic and research journal "Higher education of Ukraine" (Issue 4), (p. 12). Kyiv: Instytut vyshchoi osvity NAPN Ukrainy [in Ukrainian]. 